\title{
HKBP HIV-AIDS Committee Balige Coordination with the Regional Government HIV-AIDS Handling Program in Toba Samosir Regency 2018
}

\author{
Martinus S Tambunan ${ }^{1}$, Destanul Aulia ${ }^{2}$, Kintoko Rochadi ${ }^{3}$ \\ ${ }^{1,2,3}$ Health Policy and Administration Public Health, Universitas Sumatera Utara (USU), Medan, Indonesia \\ martinusstbn@yahoo.com
}

\begin{abstract}
The increase in the number of HIV-AIDS cases in the last ten years from 2008 to 2017 in Toba Samosir Regency with an average HIV growth of $\geq 7 \%$ and AIDS growth of $\geq 31 \%$, has to be handled by implementing a special program. The lack of coordination between HKBP AIDS Committee Balige and Regional Government has to be made since there is no similar opinion about HIV-AIDS, the government agencies which are joined in the Committee of Regional AIDS Handling are not focused on prioritizing HIV-AIDS problems, and coordination in planning has not been optimal so that the budget is limited. The objective of the research was to find out the coordination between HKBP AIDS Committee, Balige and the Regional Government in HIV-AIDS Handling program in Toba Samosir Regency. The research used qualitative method (phenomenology design) which was aimed to get information about the coordination in preventing and handling HIV-AIDS in Toba Samosir Regency, with 20 informants. The data were gathered by conducting in-depth interviews and documentary study and analyzed by using content analysis. The result of the research showed that coordination, involvement, and active participation of all agencies in the KPAD (Regional AIDS Handling Committee), the implementation of budget planning, and activity planning were inadequate. It is recommended that formal meetings be increased in order to develop communication and to create good coordination, either from budget planning or from the implementation of handling HIV-AIDS in Toba Samosir Regency.
\end{abstract}

Keywords Coordination, HKBP AIDS Balige Committee, Regional

Government

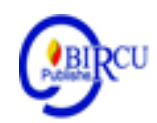

\section{Introduction}

HIV (Human Immunoeficiency Virus) is a virus that damages the immune system, by infecting and destroying CD4 cells. The more CD4 cells are destroyed, the immune system will be weaker, making it vulnerable to various diseases and AIDS is an abbreviation of Acquired Immune Deficiency Syndrome which is the impact or effect in the form of a collection of symptoms from the propagation of the HIV virus in the body of living things. WHO report on the Global AIDS Epidemic 2016, the number of global HIV-AIDS cases was 36.7 million, the number of new HIV cases was 2.3 million, and the mortality caused by AIDS was 1.5 million cases making HIV and AIDS included in the target Millennium Development Goal's / MDG's (WHO, 2016). And continued with Sustainable Development Goals (SDGs) with the target of Indonesia in 2030 the incidence of new HIV infections at the age of $15-49$ years is $0.50 / 1000$ population. 
According to the Directorate General of Disease Prevention and Control (P2P) in 2017 the Ministry of Health of the Republic of Indonesia stated that North Sumatra is the 6th highest case of HIV-AIDS nationally with 17,333 cases. The proportion of HIV-AIDS cases in Toba Samosir District has tended to increase over the last 10 years (2008 to 2017) at 8\% and AIDS by $31 \%$, with 151 HIV positive cases, and 459 AIDS cases.

According to Sucipto (2009) cumulatively, all funds sourced from the State Budget / Regional Revenues and Expenditures Budget for the prevention of HIV-AIDS in general continue to increase, but in fact not yet comparable with the level of spread of HIV-AIDS that is so high. Moreover, most of the budget (70\%) still comes from foreign aid. The low response of the budget and the program to tackle HIV-AIDS in Indonesia can actually be seen from the level of HIV transmission that continues to increase sharply.

Budgeting problems at the legislative and executive levels at this time are: (a) The process of making APBD policy is only dominated by members of the DPR, Bupati, bureaucratic officials, (b) The discussion and finalization process is still closed. APBD has not yet been fully regarded as a public document that is freely accessible to the public, (c) Low political commitment from the DPRD or bureaucracy. (Halim and Damayanti, 2007).

According to research conducted by Mitsel in 2015 through his research in Sorong, West Papua revealed that advocacy from key stakeholders in the prevention and prevention of HIV-AIDS by the KPAD and the Health Service has not been going well, and there have been no reports to key stakeholders of policy makers so that it weakens support for budget allocation in efforts to prevent and control HIV-AIDS in Sorong Regency.

The coordination of funding for HIV / AIDS prevention has not been running optimally because differences in perceptions among stakeholders still occur in the form of bureaucratic and communication barriers between government and private institutions. These bureaucratic obstacles occur because the KPAD's position as an agency mandated to coordinate is outside the organizational structure of the local government. As an adhock institution, the KPAD faced obstacles in coordinating the institutions in the local government structure, especially when dealing with the coordination of HIV-AIDS budgeting planning in the SKPD. The same thing happened in Tanzania where multisectoral coordination was more about depoliticizing HIV-AIDS because the coordinating body did not have the actual political authority to coordinate government actors or donor agencies (Hellevik, 2014).

Each institution manages its own funding and gives accountability to the donor. As a result, regions do not have accurate and comprehensive information on the magnitude, sources and flow of funds for each prevention, treatment, support and care and impact mitigation program.

\section{Review of Literature}

\subsection{Coordination in Tackling Health Problems}

Coordination as an important aspect of management requires a human resource, which includes a mindset to solve a problem. The complexity of health problems requires integrated handling, all stakeholders related to the health sector need to work together, help each other, communicate with each other, work together and complement each other in accordance with their respective duties and functions.

To overcome these various health problems, it is necessary to coordinate both across programs and with relevant stakeholders through certain mechanisms so that the implementation of activities can be integrated. The expected integration is covering various 
aspects ranging from aspects of activities, aspects of employment, aspects of funding and aspects of facilities / infrastructure.

\subsection{Indikator Koordinasi}

According to Handayaningrat (1991), coordination in the management process can be measured through indicators:

1. Communication: Communication planning is one thing that is very urgent to do in urban development activities. This is important, because communication planning aims to help achieve programs effectively and efficiently (Kholil, 2019). It is a process in which information is exchanged and understood by two or more people, usually with a view to motivating or influencing behavior (Daft, 2002). The things seen in communication are: (a) The presence or absence of information (b) The presence or absence of information flow (c) The presence or absence of information technology.

2. Awareness of the Importance of Coordination: It is that each related party must understand the importance of coordination in order to be responsible for carrying out their duties. Awareness of the importance of coordination can be seen from the first thing that is the level of the implementer's knowledge of coordination and the second thing is the level of compliance with the results of coordination

3. Participant Competence: There are authorized parties who are also involved and oversee the course of coordination. The things that can be seen in the competence of participants are: (a) The presence or absence of authorized officials involved (b) The presence or absence of experts involved.

4. Agreements, Commitments and Incentives: There is a need for agreement and commitment so that the workers who coordinate do not neglect their duties. Meaningful commitment that workers will share perspectives with leaders and enthusiastically carry out instructions. treat them fairly and offer them valuable rewards according to Daft (2002). The things that can be seen in the indicators of agreement, commitment and incentives are: (a) Whether there is a form of agreement, (b) The presence or absence of an activity, (c) The presence or absence of sanctions for violators of the agreement (d) The presence or absence of incentives for the coordinator.

5. Continuity of Planning: Future planning is needed if problems in coordination are not solved. The things seen in the continuity of planning are

(a) The presence or absence of feedback from objects and subjects in coordination (b) Whether or not there is a change in the outcome of the agreement.

In this case the author would like to look more specifically at the coordination function between the HIV-AIDS Committee of the Balige HKBP Hospital and the Regional Government through the Regent's Decree on the establishment of the Regional AIDS Management Commission. The author will examine the problem in Toba Samosir District, as a district with an increasing number of HIV-AIDS sufferers, and transmission is increasing and how it is implemented, what things affect the coordination function between the HIVAIDS Committee of the Balige HKBP Hospital and district government stakeholders Toba Samosir views the problem of HIV-AIDS as a health problem

\section{Reseach Method}

This type of research is a descriptive study with a qualitative approach, which is intended to reveal the matters relating to the coordination of HIV-AIDS prevention programs in Toba Samosir District by the HIV / AIDS Committee of Balige HKBP and local governments, how the coordination that has been going on between stakeholders involved in 
the management of the Toba Samosir District AIDS Commission in the prevention of HIVAIDS in Toba Samosir District. Culture cannot be separated from religious life, which is a manifestation of ethnic theology and cosmology (Zulkifli and Ridwan, 2019).

In obtaining information for this study researchers used

1. Primary Data: Primary data obtained using interview guides (in-depth interviews) with informants based on the interview guidelines that have been prepared.

2. Secondary Data: Secondary data in the form of evidence, notes or historical reports that have been arranged in an archive (documentary data).

\section{Findings and Discussion}

\subsection{Communication of the HKBP HIV-AIDS Committee Coordination System with} Local Governments on HIV-AIDS Control

Communication activities with the aim of accelerating efforts to treat PLWHA with assistance. According to Jumali in Wahyudiana (2001) that mentoring is a facilitation process carried out by facilitators whose role is to assist, direct and find a way towards various problems.

"So our communication is always sitting together, what we have to do there, we talk about HIV prevention, that's how it is. So we are always

In HIV / AIDS prevention activities, communication strategy is one of the important aspects for determining the success of HIV-AIDS epidemic prevention programs. This communication is intended so that the communication carried out by KPAD is effective, well targeted and has a positive impact on HIV / AIDS prevention. According to Tubbs in Grace (2007) that effective communication can produce five things, namely better relationships and actions and also understanding, pleasure, influence on attitudes.

Forms of Communication That Have Been Formed What has been going on is in the form of activities "sitting together in the sense of meetings between stakeholders". However, in its implementation, members of the KPAD management are rarely actively involved in HIV / AIDS prevention, those who are actively involved in communication activities are those offices that are actively involved in the technical countermeasures in field such as the Health Service, Social Service, BKKBN and HKBP AIDS Committee.

Obstacles felt in this communication effort are the government's attention to the response is still low as evidenced by the limited funds, and active participation, also due to bureaucratic exchanges so that new leaders in agencies involved in the management of KPADs are less aware that their duties are also included in HIV prevention -AIDS. Rahkman's research (2017) in Merauke that one of the obstacles in overcoming HIV-AIDS in Merauke is one of which is employee mutations.

\subsection{Coordination Formed between Stakeholders and Agencies in Tackling HIV-AIDS in} Toba Samosir Regency

The coordination that was formed was an effort to involve private institutions and government agencies in terms of program implementation, local government agencies involved the HKBP AIDS Committee in the effort to combat HIV-AIDS in the form of counseling, the HKBP AIDS Committee was involved as a resource. Coordination is also taking place between the health office and the Balige HKBP AIDS Committee in the 
procurement of HIV check kits from the Provincial Health Office. Coordination barriers often faced in efforts to tackle HIV-AIDS in Toba Samosir Regency are that there are no KPAD secretariat offices and staff that are active in managing planning and compiling activities, and arguments that are still felt to be weak and also data to serve as the basis for arguments for efforts to obtain fund. One effort to create good coordination is to encourage members to participate in the level of formulation, goal creation (Ketani, 2002). In this case the effort to hold a meeting directly in official forums is expected to be one of the means in the delivery of problems related to HIV / AIDS prevention, by providing direct information on matters that need to be improved, because appropriate action must be taken to create, produce the expected coordination. The things that become obstacles in carrying out coordination are differences in attitudes and ways of working that complicate tasks organization effectively namely (a) Differences in orientation towards specific objectives, (b) Differences in time orientation, (c) Differences in interpersonal orientations and, (d) Differences in structural formality.

Other barriers experienced by informants in implementing good coordination are complicated bureaucracy and frequent bureaucratic changes in the composition of the government, so that the formulation of duties, authorities and responsibilities of each work unit (work unit) is less clear (Handayaningrat, 1991). This suggests that the lack of clarity in the formulation of duties or functions, authorities and responsibilities of each official or organizational unit. The formulation of authority and responsibility must be clear because clear authority not only reduces disagreement among different employees, but also helps them in their work with united goals (Moekijat 1994). The formulation of clear tasks and division of work is to ease the programs that will be implemented and to realize good results in the process of HIV-AIDS prevention efforts in Toba Samosir District.

Based on the informant's answer, that there is no specific coordination about the steps taken, all is done individually, and this is contrary to the nature of coordination is a synchronous and orderly effort to provide the right amount and time, and direct implementation to produce a uniform and harmonious action on a predetermined target (Hasibuan, 2009).

\subsection{Participant Competencies}

In terms of tackling the HIV-AIDS problem, of course it requires the participation of all parties, including the community. The participation of people who are members of a caring organization / institution that is also very influential in tackling the HIV-AIDS problem, one of which is health cadres, Non-Government Organizations (NGOs) and media involvement.

"Non-Governmental Organizations ... Siboru Nauli NGOs with Santosa, so we have had discussions here, they are ready as a halfway house or a discussion house about $H I V$... that is ... so what has been possible is that if HIV sufferers are still stigmatized, they will keep their identities a secret, yesterday we talked about our NGO organization. There will be activities once every three months through the KPAD through the Health Office we gather at ... at their circle.

The NGO also continues to outreach to people at high risk because the presence of the NGO is closer to them, people at high risk can be more open to talk with members of this NGO. In several meetings and at the World AIDS Day commemoration NGO members are also invited to be resource persons and provide testimony (testimony) to provide information about HIV-AIDS. 
In the study it was found that not a few people with HIV who kept their status as HIV sufferers from their family and friends in their social environment, but they are more open with fellow PLWHA sufferers who are members of the NGO. Jannah's study (2014) in Riau stated that NGOs also provided knowledge about HIV, assisting HIV sufferers in undergoing drug therapy, to holding meetings to serve as a forum for people living with HIV in sharing experiences and knowledge.

The informant also stated the involvement of the media (print, electronic) in terms of disseminating information about HIV-AIDS prevention in Toba Samosir District to fill in the talk show held on the radio, at the event information was given related to HIV-AIDS and how to overcome and treatment efforts.

In line with the results of Saputra's research (2017) research on the efforts of the AIDS Commission in tackling HIV / AIDS in the city of Surabaya that for health promotion has been going well according to the target objectives but still needs to be optimized promotion methods on online media and through school material books.

\subsection{Agreement, Commitments, and Incentives}

Based on interviews conducted, that the tasks and functions contained in the Decree the establishment of KPAD, that an agreement and commitment in the response to HIV-AIDS have been determined. The agreed commitments are expected that it is expected that each agency incorporated in the management of the Toba Samosir District KPAD organization plays an active role in dealing with HIV-AIDS, with the formation of divisions within the KPAD organization namely the Service and Prevention, Communication and Information Communication (IEC) Division as well as Monitoring and Evaluation. However, only a few parties carry out their obligations.

Based on the informants' answers that the follow up of the leadership meeting of various cross-sectoral stakeholders in the HIV-AIDS prevention program is an affirmation of the conditions of the HIV-AIDS situation, and that the implementation of the tasks in accordance with the decree is carried out, joint commitment and active involvement in donating time, mind and energy in developing this HIV-AIDS prevention strategy, but to date this has not been going well.

Interdisciplinary horizontal coordination is a coordination in order to direct, unite actions, realize, and create discipline between one unit with another unit internally and externally in the units of the same task. Horizontal coordination is relatively difficult to do, because the coordinator cannot impose sanctions on officials who are difficult to regulate because his position is on the same level (Hasibuan, 2009).

Based on the informants' answers about awards or sanctions for agencies that do not fulfill / implement commitments that have never been formed and have never existed, one informant stated that because this was an additional task it was difficult to make all agencies actively involved, due to the internal busyness in their respective institutions .

\subsection{Continuity of Planning}

Further planning if the problem in coordination is not solved.

"HIV-AIDS is six times during one year and also six cases of contact tracking, the sufferers are right, patients are here when tracking contact cases ... just a house visit to follow up on case management ... six are also here"

Regulation of the Minister of Health of the Republic of Indonesia Number 71 Year 2016 Regarding Technical Guidelines for the Use of Non-Physical Special Allocation Funds 
for the 2017 Fiscal Year stipulates that: Efforts to Prevent and Control Direct Infectious Diseases (including: TB, HIV / AIDS, STIs, Hepatitis, Diarrhea, Typhoid, ARI / Pneumonia, Leprosy, yaws, etc.) with details of activities, Socialization and counseling to the community and other stakeholders, orientation to health cadres, Early case finding, Contact case tracking, Home visits for follow-up management, Mentoring, Early detection HIV / AIDS. Other informants' answers about efforts to deliver advocacy to the legislature about information on trends in the increase in HIV-AIDS cases and their relationship to budget planning and planning for HIV-AIDS prevention activities and follow-up states that there is no budget advocacy for our own HIV-AIDS funding, one informant said stated with the DPRD related to HIV / AIDS prevention if there are certain cases. Advocacy efforts for funders are still being carried out and for the DPRD itself has never been done, because we always convey to the TAD Samosir KPAD first in stages.

"But in activities there are infectious diseases but not specifically mentioned. DPRD also in this case has the element of personal interest so that they don't really want to know about this, they think of their own ego rather than the needs of society. "

The bustle of the KPAD management team, so there was no time to arrange activities. Due to various preoccupations so that activity proposals are not immediately compiled, it is necessary to also appoint special personnel, and it is not an additional task so that the secretariat office remains active and activities can continue. The answer of the third informant stated that they made an accountability report to the donor, because the funding source was from the HKBP partner agency, indirectly convince funders to continue providing financial assistance for the following years.

\section{Conclusion}

Based on the results of the study, the coordination system in overcoming HIV-AIDS is still not fully good, it can be seen from:

1. Communication by the Balige HKBP HIV-AIDS Committee as a whole to all members in the management of the KPAD is still lacking.

2. Awareness of the importance of coordination in tackling HIV-AIDS is not shared by all parties, there are still those who think that the case of HIV-AIDS is only the responsibility of the Balige HKBP HIV-AIDS Committee.

3. Competence of participants in HIV-AIDS prevention, seen from the efforts of the Balige HKBP HIV-AIDS Committee, the Health Service through talk shows about HIV-AIDS on the radio and also through print media. Likewise, the presence and involvement of NGOs who also participated as a conduit of information about HIVAIDS because of their very presence with key populations.

4. Agreements and commitments between the Balige HKBP AIDS Committee and the Regional Government are already in place in tackling HIV-AIDS, but there are still those who do not carry out their respective responsibilities in tackling HIV-AIDS, the mainstreaming of prevention activities still lies with the HKBP AIDS Committee.

5. Continuity of planning by the Balige HKBP HIV-AIDS Committee and several agencies is good even though it is only implemented by a few agencies but continuity of planning by agencies that are actively involved in terms of budgeting and activity planning is good each agency involved in HIV / AIDS prevention 
a. Reaffirm commitment and agreement in tackling HIV-AIDS to parties during a cross-sectoral meeting involved in the management of the Toba Samosir Regency KPAD.

b. Always including the HIV-AIDS prevention program is one of the important programs in every planning in each agency

c. To the Chairperson of the HIV-AIDS Prevention Commission in order to maximize its function as a manager and coordinator, to further improve the cross-sectoral coordination system in HIV-AIDS Prevention in Toba Samosir district.

d. So that the KPAD office is clear in its position, and has an executor who is able to manage the KPAD secretariat office in a sustainable manner. This staff is full time, has experience in strategy and budget planning and HIV / AIDS prevention

e. To the Toba Samosir District Health Office and Porsea Regional Hospital as implementers in order to increase financial budgeting so that health promotion and VCT efforts within the Toba Samosir District Health Office can be maximized.

f.The HKBP HIV-AIDS Committee always continues to foster good cooperation with agencies under the auspices of the Regional Government of Toba Samosir Regency

\section{References}

Daft, R., L.(2002). ManajemenEdisi Kelima Jilid Satu. Jakarta : Erlangga.

Ditjen P2P.(2017). Laporan Perkembangan HIV- AIDS Triwulan 1, Kementerian Kesehatan Repubik Indonesia, Jakarta.

Halim, Damayanti. (2007).Pengelolaan Keuangan Daerah, Yogyakarta : UPP STIM YKPN.

Handayaningrat, S.(1991). Pengantar llmu Administrasi, Jakarta: Penerbit : PT. Gunung Agung.

Hasibuan M,S.P.(2013). Manajemen Sumber Daya Manusia, Cetakan Ketujuh Belas, Jakarta: Penerbit Bumi Aksara.

Ketani, Nurlela.(2002). Azas-azas Manajemen, Medan.

Kholil, S. (2019). Communication Planning of Langsa City Government in Buildingan Islamic and Environmentally Friendly City. Budapest International Research and Critics Institute-Journal (BIRCI-Journal). P. 638-644.

Moekijat., (1994). Koordinasi Suatu Tinjauan Teoritis, Bandung : Mandar Maju.

Rakhman, R. (2017). Peran Pemerintah Daerah dalam Pencegahan dan Penanggulangan HIVAIDS di Kabupaten Merauke, Skripsi.

Saputra, O. (2015). Jurnal Ilmu Administrasi Negara, Upaya Komisi Penanggulangan AIDS dalam Menanggulangi HIV dan AIDS di Kota Surabaya.

Zulkifli and Ridwan, Muhammad. 2019. Revitalization of the traditional values lost due to the commodification of art/crafts: a case study of Bataknese traditional Ulos. Asian Ethnicity, 541-554. 